\title{
The study of mRNA Expression of Dopamine Receptors D2 and D3 in Schizophrenic Patients
}

\author{
Azza M Abdu Allah', Eman M Abd El Gayed', Amr S Shalaby², \\ Bothaina M Afifi ${ }^{1}$
}

Medical Biochemistry and Molecular Biology Department ${ }^{1}$, Psychiatry Department $^{2}$, Faculty of Medicine, Menoufia University, Egypt

Received 16/9/2018 - Accepted 10/10/2018

\begin{abstract}
Schizophrenia is a severe mental disorder affecting behavior, thought and emotions in the form of hallucinations, delusions and cognitive impairment. Dopamine system is implicated in the pathogenesis of schizophrenia through dopamine receptors expression in the brain. The aim of this work is to evaluate the role of mRNA expression of dopamine receptors D2 and D3 in the diagnosis of schizophrenia. Thirty-five schizophrenic patients and fifteen age and gender matched healthy controls were included in this study. Serum lipid profiles were determined by enzymatic colorimetric method while the determination of dopamine receptors D2 and D3 mRNA expression was performed by real time q PCR technique. There was significant statistical decrease of $H D L-c$ and increase of $L D L-c$ in patients compared to control group, while Cholesterol and TAG showed no significant statistical difference between the two groups. There was significant increase of the $m R N A$ expression of dopamine receptors D2 and D3 genes in the blood of the patients compared to control group ( $p$ value $=0.001$ and $<0.001$ respectively). From this study, it could be concluded that Dopamine receptors D2 and D3 mRNA expression in the blood might be used as diagnostic markers of schizophrenia, revealing the importance of dopamine receptors antagonist as antipsychotics.
\end{abstract}

Key words: Schizophrenia, dopamine D2 receptors, dopamine D3 receptors, $m R N A$ expression.

*This was taken from thesis submitted to partial fulfillment of MSc degree in Medical Biochemistry by Bothaina Mahmoud Afifi.

* Carrespondence Author (e mail yojena0000@gmail.cam) 


\section{INTRODUCTION}

Schizophrenia is a debilitating neuropsychiatric disorder with a lifetime incidence of approximately $1 \%$ worldwide that impairs mental and social functioning and often leads to the development of comorbid diseases (Philip et al., 2016). Individuals with schizophrenia may experience positive, negative and cognitive symptoms. Traditional positive symptoms alter the patient's sense of reality. It means things "added" or "new" to the personality. It includes hallucinations (presence of perceptual aberrations) that may be auditory, visual and tactile delusions and confused thoughts and speech (Young and Geyer, 2015). Negative symptoms include decreased daily activities, socialization, flat affect and alogia (Foussias et al., 2014).

Dopamine (DA) is a catecholamine neurotransmitter that is a precursor to the synthesis of the neurotransmitters norepinephrine (NE) and epinephrine (Wang et al., 2014) involved in pleasure and reward through mesolimbic pathway (Ayano et al., 2016) and highly involved in cognition, working memory, and decision making through mesocortical pathway (Yadav et al., 2014). Dopamine action is mediated by five subtypes of dopamine receptors, D1 family including (D1and D5 receptors) and D2 family including (D2, D3 and D4 receptors) which are members of the large G-protein coupled receptor (GPCRs) super family (Ayano, 2016).

They are encoded in humans by genes DRD1, DRD2, DRD3, DRD4 and DRD5 mediating the physiological functions of dopamine (Beaulieu et al., 2015). D1- family activate the Gs/olf family of $G$ proteins stimulating cAMP production by Adenylyl Cyclase and are found exclusively postsynaptically on dopamine-receptive cells, while D2-family couple to the Gi/olf family of $\mathrm{G}$ proteins inhibiting Adenylyl Cyclase and are expressed both postsynaptically on dopamine target cells and presynaptically on dopaminergic neurons (Rondou et al., 2010). The "original dopamine hypothesis" states that hyperactive dopamine transmission results in schizophrenic symptoms (Madras BK, 2013). There is enhanced presynaptic DA in basal ganglia responsible for positive symptoms, while the negative and cognitive symptoms of schizophrenia can be attributed to a reduced dopaminergic tone in cortical areas (Kuepper et al. 2012). 
In human brain, D3R mRNA has been detected in nucleus accumbens where their concentration is particularly high in the ventral stratum responsible for psychotic symptoms playing a role in cognitive and emotional functions (Maramai et al., 2016). D3 antagonism was found to improve certain cognitive spheres by increasing acetylcholine release at the prefrontal cortex level disinhibiting the activity of dopamine neurons projecting to the nucleus accumbens or prefrontal cortex, or activating cAMP-response element-binding protein (CREB) signaling in the hippocampus which act as neuroprotective (Nakajima et al., 2013).

The aim of this work is to evaluate the role of mRNA expression of dopamine receptors D2 and D3 in the diagnosis of schizophrenia.

\section{MATERIALS AND METHODS}

This study was carried out at Medical Biochemistry and Psychiatry Departments, the patients were attendants of outpatient clinic and from inpatient department of Psychiatry at the first day of admission, Menoufia University Hospital during the period from May to November 2017.

50 subjects were enrolled in the study; they were 35 schizophrenic patients (15 males and 20 females) with mean age $\mathrm{X} \pm \mathrm{SD}$ was $34.57 \pm 8.89$ and 15 age and gender matched healthy controls (8 males and 7 females) with mean age of $35.47 \pm 12.69$. The study was approved by ethical committee of Faculty of Medicine, Menoufia University. A written informed consent was obtained from all subjects.

Diagnosis of schizophrenia was based on the Diagnostic and Statistical Manual of Mental Disorders, Fifth Edition, (DSM-5), that states that for the diagnosis of schizophrenia, the patient must have experienced at least 2 of the following symptoms: (Delusions, Hallucinations, Disorganized speech, Disorganized or catatonic behavior and Negative symptoms).

Two (or more) of the following must be present; (delusions, hallucinations, disorganized speech, catatonic behavior and negative symptoms) for at least 6 months, during which the patient must experience at least 1 month of active symptoms (or less if successfully treated), with social or occupational deterioration problems occurring over a significant amount of time. Schizoaffective disorder, depressive 
and bipolar disorder with psychotic features and any substance addiction have been ruled out. (Ezequiel 2016).

Exclusion criteria: Patients with mental retardation, a past history of head trauma, a serious neurologic disorder (epilepsy, stroke, Parkinson's disease, dementia) and who had an acute, unstable, significant medical illness were excluded from this study.

All participants were subjected to the following: Full assessment of history including (age, gender, occupation, residence and the age of onset and duration of disease), a thorough clinical examination, pulse and blood pressure (systolic, diastolic). Laboratory investigations include measurement of lipid profile [serum total cholesterol (TC), triglycerides (TG), high-density lipoprotein cholesterol (HDL-c) and low-density lipoprotein cholesterol (LDL-c)] and determination of dopamine receptors D2 and D3 genes $m R N A$ expression performed by real time q PCR using technique.

\section{Samples collection:}

Five milliliters (ml) of venous blood were taken from each subject and divided as follows: $\mathbf{3} \mathbf{~ m l}$ were put in plain tube left to clot for 30 minutes at room temperature then subjected to centrifugation for 10 minutes at 4000 r.p.m. The serum obtained was separated and stored at $-80^{\circ} \mathrm{C}$ until determination of serum HDL-c, serum TG cholesterol and serum LDL-c. $2 \mathrm{ml}$ of blood were transferred into EDTA containing tube for determination of Dopamine receptor D2 and D3 genes mRNA expression by RT-qPCR.

\section{Assay methods:}

Serum total cholesterol and triglycerides and high-density lipoprotein cholesterol (HDL-c) were determined by enzymatic colorimetric test, using BioMerieux kit, France, serum HDL-c (Grove, 1979), serum TG (Deska et al., 2005), cholesterol (Amundson et al., 1999) and serum LDL-c (friedewald et al., 1972). While serum lowdensity lipoprotein (LDL cholesterol was calculated by friedewald equation as LDL-c $=($ total cholesterol $)-[$ (high density lipoprotein cholesterol [HDL-c]) + (Triglycerides /5)] in mg/dl (friedewald et al., 1972).

\section{Estimation of gene expressions}

The Thermo Scientific GeneJET Whole Blood RNA Purification Mini Kit was used for the isolation of RNA from peripheral blood leukocytes (PBL) as (PBL) expresses dopamine receptors and 
dopamine transporters and synthesize endogenous dopamine through tyrosine hydroxylase dependent pathway (Ahmadian et al., 2014), then first-step PCR: complementary DNA was synthesized using High-Capacity cDNA Reverse Transcription Kits (Applied Biosystems, USA, 2012) second step-PCR (real time Polymerase Chain Reaction): it was performed using QuantiTect SYBR Green PCR Kit with ready-made primer assay (Invitrogen, Thermo Fisher scientific). For the detection of Dopamine receptors DRD2 and DRD3 mRNA levels, the following primers were used: forward and reverse primers for human DRD2, 5'- AGACCATGAGCCGTAGGAAG-3' and 5'- GCAGCCAGCAGATGATGA-3', respectively; forward and reverse primers for human DRD3 5'CAACCCTGATTTTGTCATCTACTCT-3'and 5'CTTTGTTTCAGCACCACATAGATTC-3', respectively; forward and reverse primers for human $\beta$-Actin, 5'GAGCGGGAAATCGTGCGTGACATT-3' and 5'GAAGGTAGTTTCGTGGATGCC-3' respectively. PCR was conducted under the following conditions: Each reaction for each gene was performed in a final volume $20 \mu \mathrm{L}$, containing, $10 \mu \mathrm{l} 2 \mathrm{x}$ QuantiTect SYBR Green PCR Master Mix, $3 \mu$ Template cDNA, 1ul forward primer, 1 ul reverse primer and $5 \mu \mathrm{l}$ Rase-free water. The mix was incubated at $95 \mathrm{c}$ for 15 minutes followed by 45 cycles: denaturation at $94^{\circ} \mathrm{C}$ for $15 \mathrm{~s}$, annealing at $58^{\circ} \mathrm{C}$ for $30 \mathrm{~s}$ and extension at $72^{\circ} \mathrm{C}$ for $30 \mathrm{~s}$. Data analysis using Applied Biosystems 7500, software version 2.0.1. The relative quantitation (RQ) of gene expression performed using Comparative $\Delta \Delta \mathrm{Ct}$ method (Dorak, 2000). DRD2 and DRD3 mRNA levels were normalized to the mRNA level of housekeeping gene B actin. Melting curve was performed to confirm specificity of the amplification and absence of primer dimers. 


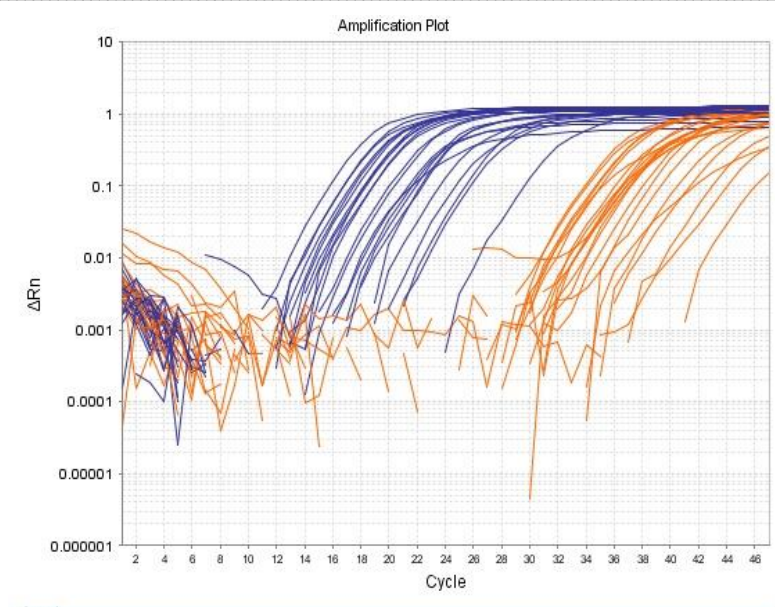

Bactin DD2

Figure 1: Amplification plot of DRD2 mRNA gene expression (normalized fluorescence signal $(\Delta \mathrm{Rn})$ plotted versus cycle number).

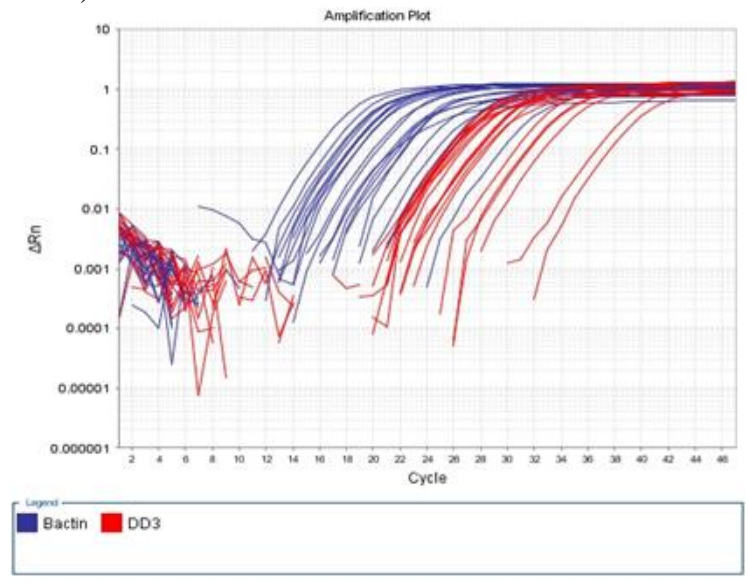

Figure 2: Amplification plot of DRD3 mRNA gene expression (normalized fluorescence signal $(\Delta \mathrm{Rn})$ plotted versus cycle number). 
The study of $m$ RnAt Expression of Dopamine Receptors ........

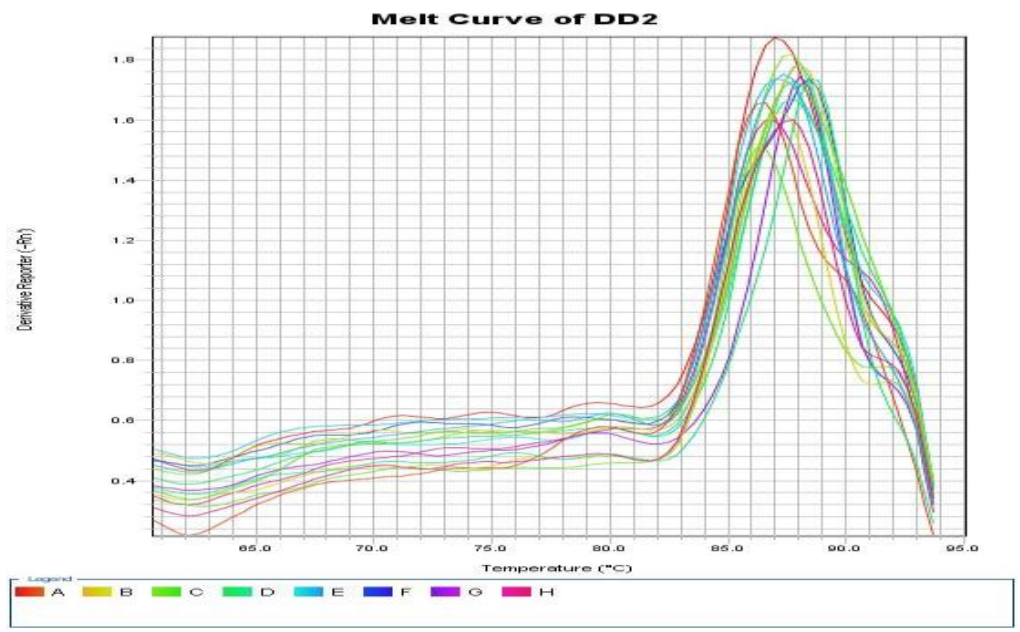

Figure 3: Melting curve of DD2

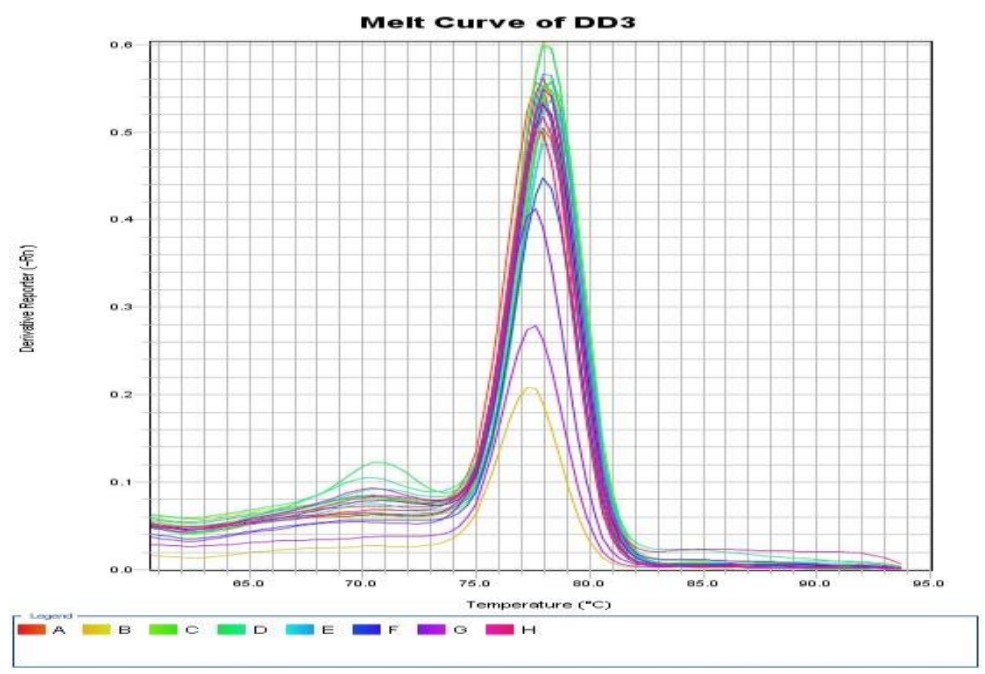

Figure 4: Melting curve of DD3 


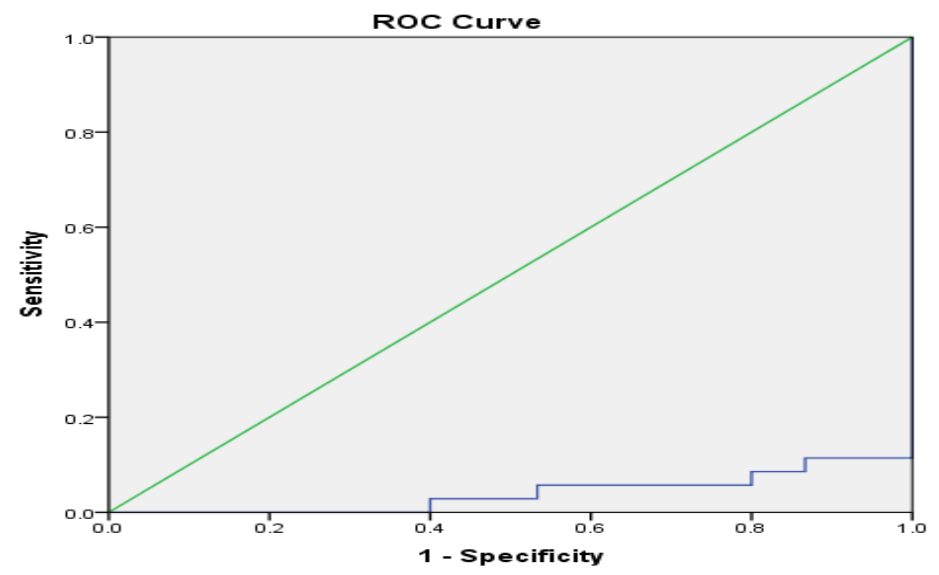

Figure 5: ROC curve of DD2

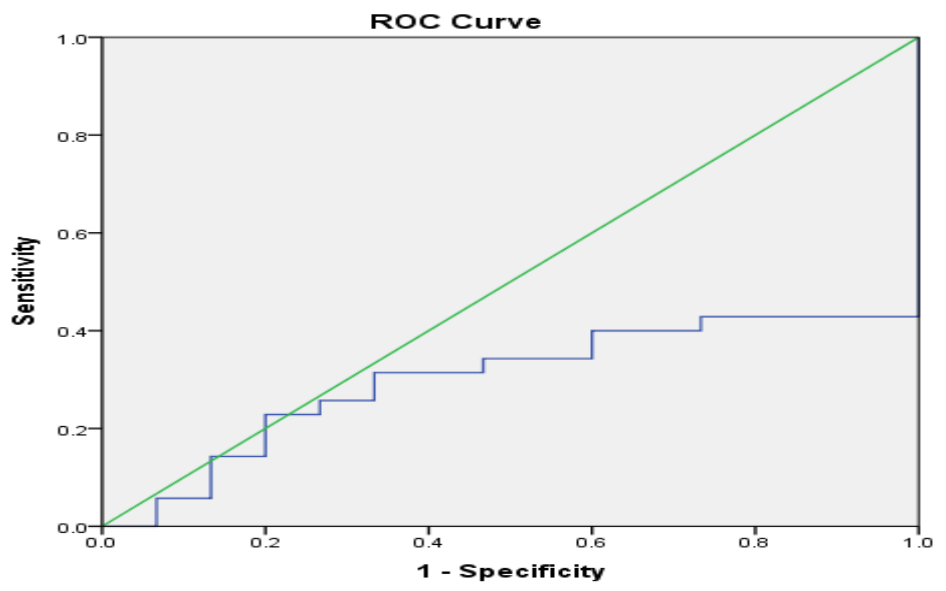

Figure 6: ROC curve of DD3 


\section{Statistical analysis:}

The data collected was tabulated and analyzed by SPSS (statistical package for the social science) software version 20. Chisquare test is used to study the association between two qualitative variables. Student's t test was used to assess the statistical significance of parametric data. Spearman's correlation was used for skewed distributed quantitative variables. Odds ratio (OR) describes the probability that people who are exposed to a certain factor disease compared to people who are not exposed to the factor. Values less than 0.05 were considered significant.

\section{RESULTS}

The results show that there is non-significant statistical difference between studied groups regarding age and gender while there is significant statistical difference between studied groups regarding cognitive symptoms, positive symptoms and negative symptoms (Table 1). There was significant statistical increase in the mRNA expression of dopamine receptors D2 and D3 in the blood of group I compared to group II (Table 2). There was significant statistical decrease of HDL-c and increase of LDL-c in group I when compared to group II, while There is no significant statistical difference of Cholesterol and TAG when group I compared to group II (Table 3).There was no significant statistical difference between HDL in patients with suicidal attempts and those with no suicidal history in group I, while there was significant statistical decrease of LDL, Cholesterol and TAG in patients with suicidal attempts regarding those with no suicidal history in group I (Table 4). There was nonsignificant correlation between dopamine receptors D2 and D3 mRNA expression and age in both studied groups (Table 5).There was non-significant correlation between dopamine receptors D2 mRNA expression and lipid profile in both studied groups (Table 6).There was non-significant correlation between dopamine receptors D3 mRNA expression and HDL-c in both studied groups, while there is positive correlation between dopamine receptors D3 mRNA expression and LDL-c, Cholesterol and TAG in patient group (Table 7).Multivariate logistic regression for risk of schizophrenia showed that the most common risk factor is DRD3 OR; 12.3 (0.01-11.4), followed by DRD2 OR; 5.8 (0.2-9.7) (Table 8). The ROC curve was 
applied to assess the diagnostic utility of DD2 and DD3 mRNA expression in control versus schizophrenic patients (Figures 5\&6). It revealed that the best cutoff point for DD2 is 21.4 and for DD3 is 24.5. DD2 had a diagnostic sensitivity of $87 \%$, specificity of $93.3 \%$, with a positive predictive value of $79.4 \%$ and negative predictive value of 100 while DD3 had a diagnostic sensitivity of $94.3 \%$, specificity of $86.7 \%$, with a positive predictive value of 89.6 and negative predictive value of 100 (Table 9).

Table (1): Demographic characteristics of the studied groups:

\begin{tabular}{|c|c|c|c|c|c|c|}
\hline \multirow[t]{2}{*}{ Item } & \multicolumn{2}{|c|}{$\begin{array}{l}\text { Control } \\
(\mathbf{N}=15)\end{array}$} & \multicolumn{2}{|c|}{$\begin{array}{l}\text { Case } \\
(\mathbf{N}=35)\end{array}$} & \multirow[t]{2}{*}{$\chi^{2}$} & \multirow[t]{2}{*}{$P$ value } \\
\hline & No & $\%$ & No & $\%$ & & \\
\hline Age $($ mean \pm SD $)$ & \multicolumn{2}{|c|}{$35.47 \pm 12.69$} & \multicolumn{2}{|c|}{$34.57 \pm 8.89$} & $0.28 * *$ & 0.8 \\
\hline $\begin{array}{l}\text { Gender: } \\
\text { female } \\
\text { male }\end{array}$ & $\begin{array}{l}7 \\
8\end{array}$ & $\begin{array}{l}25.9 \\
34.8\end{array}$ & $\begin{array}{l}20 \\
15\end{array}$ & $\begin{array}{l}74.1 \\
65.2\end{array}$ & 0.47 & 0.5 \\
\hline $\begin{array}{l}\text { Cognitive: } \\
\text { No } \\
\text { Yes }\end{array}$ & $\begin{array}{l}15 \\
0\end{array}$ & $\begin{array}{l}38.5 \\
0.0\end{array}$ & $\begin{array}{l}24 \\
11 \\
\end{array}$ & $\begin{array}{l}61.5 \\
100.0 \\
\end{array}$ & 6.1 & $0.01 *$ \\
\hline $\begin{array}{l}\text { Positive symptoms: } \\
\text { No } \\
\text { Yes }\end{array}$ & $\begin{array}{l}15 \\
0 \\
\end{array}$ & $\begin{array}{l}93.8 \\
0.0 \\
\end{array}$ & $\begin{array}{l}1 \\
34 \\
\end{array}$ & $\begin{array}{l}6.2 \\
100.0 \\
\end{array}$ & 45.5 & $<0.001 *$ \\
\hline $\begin{array}{l}\text { Negative symptoms: } \\
\text { No } \\
\text { Yes }\end{array}$ & $\begin{array}{l}15 \\
0\end{array}$ & $\begin{array}{l}51.7 \\
0.0\end{array}$ & $\begin{array}{l}14 \\
21\end{array}$ & $\begin{array}{l}48.3 \\
100.0\end{array}$ & 15.5 & $<0.001 *$ \\
\hline
\end{tabular}

$* *$ independent $t$-test, $* \mathbf{p}<0.05$ is considered statistically significant, $\chi 2$ : Chi square test

Table (2): Statistical comparison of DR $2 \& 3$ mRNA expressions between both studied groups:

\begin{tabular}{|l|l|l|l|l|}
\hline Item & $\begin{array}{l}\text { Control } \\
(\text { mean } \pm \text { SD })\end{array}$ & $\begin{array}{l}\text { Case } \\
(\text { mean } \pm \text { SD })\end{array}$ & $* * \mathbf{U}$ & P value \\
\hline DD2 & $0.43 \pm 0.23$ & $8.8 \pm 9.4$ & 3.43 & $\mathbf{0 . 0 0 1 *}$ \\
\hline DD3 & $0.39 \pm 0.22$ & $10.59 \pm 8.8$ & 4.43 & $<\mathbf{0 . 0 0 1 *}$ \\
\hline
\end{tabular}

* $\mathbf{p}<0.05$ is considered statistically significant $\quad * * U$ Mann-Whitney test 
Table (3): Statistical comparison of lipid profile between both studied groups:

\begin{tabular}{|l|l|l|l|l|}
\hline Item & Control $(\mathbf{N = 1 5 )}$ & Case $\mathbf{( N = 3 5 )}$ & $\begin{array}{l}\text { t- } \\
\text { value }^{* *}\end{array}$ & P value \\
\hline $\begin{array}{l}\text { HDL-c } \\
(\mathbf{m g} / \mathbf{d l})\end{array}$ & $60 \pm 8.4$ & $45.78 \pm 7.8$ & 5.8 & $<\mathbf{0 . 0 0 1 *}$ \\
\hline $\begin{array}{l}\text { LDL-c } \\
(\mathbf{m g} / \mathbf{d l})\end{array}$ & $102.36 \pm 16.9$ & $144.06 \pm 54.2$ & 2.9 & $\mathbf{0 . 0 0 6} *$ \\
\hline $\begin{array}{l}\text { Cholesterol } \\
\text { (mg/dl) }\end{array}$ & $181.08 \pm 13.37$ & $211.6 \pm 66.18$ & 1.8 & 0.08 \\
\hline TAG (mg/dl) & $101.35 \pm 24.38$ & $125.4 \pm 70.69$ & 1.3 & 0.2 \\
\hline
\end{tabular}

Table (4): Relation between suicidal attempts and lipid profile:

\begin{tabular}{|l|l|l|l|l|}
\hline Item & $\begin{array}{l}\text { No suicide } \\
(\mathbf{N = 1 8})\end{array}$ & $\begin{array}{l}\text { Suicide } \\
(\mathbf{N = 1 7 )}\end{array}$ & $\begin{array}{l}\text { t- } \\
\text { value }^{* *}\end{array}$ & P value \\
\hline HDL-c(mg/dl) & $45.72 \pm 8.9$ & 45.85 & 0.05 & 0.9 \\
\hline LDL-c(mg/dl) & $184.69 \pm 30.4$ & 101.05 & 7.2 & $<\mathbf{0 . 0 0 1 *}$ \\
\hline Cholesterol(mg/dl) & $266.7 \pm 34.1$ & $153.3 \pm 32.1$ & 10.1 & $<\mathbf{0 . 0 0 1 *}$ \\
\hline TAG(mg/dl) & $181.8 \pm 39.1$ & $65.8 \pm 40.6$ & 8.6 & $<\mathbf{0 . 0 0 1 *}$ \\
\hline
\end{tabular}

Table (5): Correlation between each of dopamine $2 \& 3$ mRNA expression with age of participants in both groups:

\begin{tabular}{|l|l|l|l|l|}
\hline \multirow{2}{*}{ Item } & \multicolumn{2}{|l|}{$\begin{array}{l}\text { Control } \\
\text { Age }(\text { mean } \pm \text { SD): } \\
(35.47 \pm 12.69)\end{array}$} & \multicolumn{2}{l|}{$\begin{array}{l}\text { Case } \\
\text { Age }(\text { mean } \pm \text { SD): } \\
(34.57 \pm 8.89)\end{array}$} \\
\cline { 2 - 5 } & R & P value & R & $\begin{array}{l}\text { P } \\
\text { value }\end{array}$ \\
\hline DD2 & 0.29 & 0.28 & -0.04 & 0.8 \\
\hline DD3 & 0.18 & 0.5 & 0.14 & 0.4 \\
\hline
\end{tabular}

Table (6): Correlation between DR2 mRNA expression and lipid profile

\begin{tabular}{|l|l|l|l|l|}
\hline \multirow{2}{*}{ Item } & \multicolumn{2}{l}{ Control (DR2 mRNA) } & \multicolumn{2}{l|}{ Case (DR2 mRNA) } \\
\cline { 2 - 5 } & r & P value & r & P value \\
\hline HDL-c(mg/dl) & 0.08 & 0.79 & 0.07 & 0.6 \\
\hline LDL-c(mg/dl) & -0.34 & 0.2 & -0.02 & 0.9 \\
\hline $\begin{array}{l}\text { Cholesterol } \\
\text { (mg/dl) }\end{array}$ & -0.4 & 0.14 & 0.05 & 0.8 \\
\hline TAG (mg/dl) & -0.26 & 0.36 & 0.08 & 0.6 \\
\hline
\end{tabular}


Table (7): Correlation between DR3 mRNA expression and lipid profile:

\begin{tabular}{|l|l|l|l|l|}
\hline \multirow{2}{*}{ Item } & \multicolumn{2}{|l|}{ Control (DR3 mRNA) } & \multicolumn{2}{l|}{ Case (DR3 mRN) } \\
\cline { 2 - 5 } & $\mathbf{r}$ & P value & R & P value \\
\hline $\begin{array}{l}\text { HDL } \\
\text { (mg/dl) }\end{array}$ & 0.09 & 0.8 & 0.06 & 0.7 \\
\hline LDL(mg/dl) & -0.19 & 0.5 & 0.52 & $\mathbf{0 . 0 0 1} *$ \\
\hline $\begin{array}{l}\text { Cholesterol } \\
(\mathbf{m g} / \mathbf{d l})\end{array}$ & -0.09 & 0.7 & 0.57 & $<\mathbf{0 . 0 0 1 *}$ \\
\hline TAG(mg/dl) & -0.19 & 0.5 & 0.6 & $<\mathbf{0 . 0 0 1 *}$ \\
\hline
\end{tabular}

* $\mathbf{p}<0.05$ is considered statistically significant

Table (8): multivariate logistic analysis of schizophrenia risk factors:

\begin{tabular}{|l|l|l|l|l|}
\hline & B & OR & CI (95\%) & P value \\
\hline DRD2 & 3.2 & 5.8 & $0.2-9.7$ & $<\mathbf{0 . 0 0 1 *}$ \\
\hline DRD3 & 5.9 & 12.3 & $0.01-11.4$ & $<\mathbf{0 . 0 0 1 *}$ \\
\hline
\end{tabular}

*regression coefficient

Table (9): Performance characteristics of mRNA of DD2 and DD3 in differentiating between schizophrenic patients and control:

\begin{tabular}{|l|l|l|l|l|l|l|l|}
\hline parameters & AUC & $\begin{array}{l}\text { Cut } \\
\text { off } \\
\text { point }\end{array}$ & Sensitivity & Specificity & PPV & NPV & Accuracy \\
\hline DD2 & 0.04 & 21.4 & $87 \%$ & $93.3 \%$ & 79.4 & 100 & 91.7 \\
\hline DD3 & 0.03 & 24.5 & $94.3 \%$ & $86.7 \%$ & 89.6 & 100 & 94.7 \\
\hline
\end{tabular}

AUC: (Area Under the Curve), PPV: (positive predictive value), NPV: (negative predictive value)

\section{DISSCUSION}

The term schizophrenia was coined in the early 1900s by Paul Eugen Bleuler, a Swiss psychiatrist, who used the Greek words skhizein (to split) and phrēn (mind) (Janoutová et al., 2016). Dopamine is an inhibitory neurotransmitter involved in the pathology of schizophrenia acting through dopamine receptors (Brisch et al., 2014).

D2 receptors is the main target for antipsychotic treatment and overactivity of dopamine D2 receptors can be the basis of positive symptoms of schizophrenia such as hallucinations and delusions, and 
it can also be the basis of cognitive difficulties (Peng et al., 2016). $D 3$ receptors are unique, exhibiting sustained high affinity for DA (>20-fold higher than D2 receptors), suggesting that D3 receptors in vivo may be occupied by endogenous DA for longer periods, leading to high spontaneous activation of D3 which can modulate cortical control of cognitive functions via their inhibitory effect on mesocortical dopaminergic activity (Gross and Drescher, 2012).

The pathophysiology of schizophrenia involves immune- and inflammatory pathways, integrated with redox-regulation which affects the composition of membrane lipids and also affects serum lipids causing dyslipidemia. Thus, the abnormalities of both serum and membrane lipids and the change in membrane lipid composition in neuronal cells can affect neurotransmission, symptoms and behavior in schizophrenia (Solberg et al., 2016).

Membrane polyunsaturated fatty acids (PUFAs) are significantly decreased in both the central nervous system and RBCs of patients with schizophrenia (Hone et al., 2013).

(PUFAs) the main material of membranes and play a role in myelination being essential constituents of all cell membranes and the myelin sheaths around the axons. They are vulnerable to damage by free radicals due to their double-bond structure (lipid peroxidation) which leads to damages of cell membrane fluidity and permeability, signal transduction by decreasing arachidonic acid concentration which is correlated with greater severity of negative symptom of schizophrenia (Peters et al., 2013).

The current study showed that age and gender were matched between patients and control. There was no significant statistical difference $(p>0.05)$ between studied groups regarding age and gender. These results are in agreement with those reported by (Zhang et al., 2017 and Ramakrishna et al., 2017).

Regarding clinical presentation in present study, there was significant statistical difference between patients and controls regarding cognitive symptoms $(\mathrm{p}=0.01)$, negative symptoms $(\mathrm{p}<0.001)$ and positive symptoms $(\mathrm{p}<0.001)$. These results are in agreement with those reported by (Gauri et al., 2013, Fatouros-Bergman et al., 2014, Sarkar et al., 2015 and Mitra et al., 2016). Gauri et al., (2013) reported that significant deficits in social and emotion perception were associated with schizophrenic patients, and the longer the duration of illness, the greater the deficit symptoms. Fatouros-Bergman et al., 
(2014) reported that patients had worse cognitive domains (verbal memory, speed of processing and working memory) than healthy controls and confirmed that cognitive deficits are present also in drugnaïve patients at an early stage of the illness.

The present study showed that the patient group had significant statistical increase $(p<0.001)$ of mRNA expression of dopamine receptors D3 in the blood of schizophrenic patients compared to control group. These results agree with those reported by (Ahmadian et al., 2014, Cui et al., 2015 and Asaad et al., 2018). Cui et al., (2015) reported that the mRNA expression level of DRD3 in the blood of patients with schizophrenia was significantly greater than that of the controls. They reported that DRD3 is preferentially localized in limbic areas, having a role in emotions, motivation, and reward with higher levels of mRNA were expressed in the nucleus accumbens. This was observed in the brains of drug-free schizophrenic patients, but not in medicated patients at the time of death reflecting that the increased expression of DRD3 mRNA in $\mathrm{T}$ lymphocytes may reflect hyperdopaminergic neurotransmission in the brain.

Our study revealed that patient group had significant statistical increase $(p=0.001)$ of mRNA expression of dopamine receptors D2 genes in the blood of schizophrenic patients when compared to control group this was in accordance with (Lai CY et al., 2016 and Liu et al., 2017).

Lai et al., (2016) reported that the levels of lymphocyte DRD3 mRNA was reported to be elevated in both people with chronic schizophrenia and people with drug naïve schizophrenia. They also reported both mRNA expression and receptor binding of DRD2 were increased in lymphocytes from people with drug naïve schizophrenia. Striatal hyperdopaminergic state is a significant finding in schizophrenia through overexpression of striatal D2 receptors which is associated with impairments in working memory One et al., (2018).

In contrast with our study, Kawano et al., (2011) and UrhanKucuk et al., (2011) reported that there were no statistically significant differences in the levels of these DRD3 receptor mRNAs in schizophrenic patients and controls. Furthermore, in other studies there was no significant differences in the DRD2 mRNA levels between the schizophrenic patients and controls, so DRD2 mRNA levels in the blood may be related to the severity of psychiatric 
symptoms, but not a diagnostic marker of schizophrenia (Liu et al., 2013 and Cui et al., 2015).

The present study showed that patient group had significant statistical decrease of serum HDL-c ( $\mathrm{p}<0.001)$ when compared to control group. These results are in accordance with those reported by (Wu et al., 2014 and Ono et al., 2018) as they reported that by comparison with first-episode, drug-naïve patients with schizophrenia, antipsychotic-treated patients with schizophrenia had lower plasma HDL-c levels. Solberg et al., (2015) reported that HDL-c levels were also significantly lower in the patients with schizophrenia that were not using an antipsychotic medication compared with healthy controls. Our study reported that there was significant statistical difference when comparing schizophrenic patient with control regarding serum LDL-c $(p=0.006)$. These results agree with those reported by Mensi et al., (2016). The current study reported that there was no significant statistical difference regarding serum cholesterol and TAG when comparing patients and control group. These results are in agreement with (Ramakrishna et al., 2017 and Solberg et al., 2016).

Ramakrishna et al., (2017) reported that there was no significant difference in mean triglycerides between untreated schizophrenic patients and control group and Solberg et al., (2016) who reported that the difference in cholesterol between patients and healthy controls was not significant.

In contrast to our study Solberg et al., (2016) reported that the levels of triglyceride were significantly higher in patients with schizophrenia than in healthy controls. They found that the patients did not receive antipsychotic treatment when TAG was measured, so the higher levels of serum triglyceride may be associated with the disease itself, and not only a result of medication.

The present study showed that patient group with suicidal attempts history had significant statistical decrease $(p<0.001)$ of serum LDL$\mathrm{c}$, cholesterol and TAG compared to patients without suicide history, while no difference between HDL-c of both groups. These results agree with those reported by Ainiyet B. et al., (2014). Lalovic et al., (2010) reported that -mortem study reported down regulation of lipid metabolism mortem genes in the frontal cortex of suicide completes. Mensi et al., (2016) matched our results regarding to total cholesterol and HDL-c but they reported no significant difference between LDL-c and TAG of both groups. 
There is a neurochemical connection between suicide and reduced levels of serum cholesterol as current hypotheses suggest a decreased serotonergic activity through altered affinity and function of serotonin receptors and transporters due to a decrease in cholesterol in the lipid rafts of synaptic membranes. Other mechanisms have been explained that increased impulsivity in suicidal individuals, including steroid modulation and brain-derived neurotrophic factor decrease, which could also be related to changes in lipid raft and reduction in the lipid viscosity of neuronal cell membranes Cantarelli et al., (2014).

The current study reported that there is non-significant correlation between dopamine receptors D2 and D3 mRNA expression and age in both studied groups. These results agree with those reported by (Liu et al., 2013 and Asaad et al., 2018).

Moreover, the current study reported that there was positive correlation between dopamine receptors D3 mRNA expression and LDL-c, Cholesterol and TAG in both groups. There is an evidence that high cholesterol levels may be important to human learning and memory. Elevated serum cholesterol is a risk factor for mild cognitive impairment and showed the level of the cholesterol precursors lanosterol and lathosterol during cholesterol synthesis are correlated with low memory performance Schreurs., (2010).

Furthermore, the current study reported that DRD3 and DRD2 mRNA expression in blood can be considered as a risk factor for developing schizophrenia. DRD2 mRNA levels in peripheral blood of drug-naive schizophrenic patients were found to be over-expressed and the receptor binding of DRD2 was increased (Liu et al., 2013 and Lai et al., 2016). Research by the Psychiatric Genomic Consortium (PGC) supported the notion that the DRD2 gene coding for the D2 dopaminergic receptor is associated with risk for schizophrenia and its genetic variation has been linked with types of schizophrenia and its treatment Pergola et al., (2017). DRD3 was reported to have a possible clinical significance for being a rapid diagnostic marker for people who are suspicious of schizophrenia, according to (Ahmadian et al., 2014 and Cui et al., 2015).

The current study revealed high sensitivity and specificity of D2 and D3 receptors in schizophrenic patients making them can be used as prognostic markers of schizophrenia. 
In accordance with our study Asaad et al., (2018) and Ilani et al., (2001) reported that D3 receptors in lymphocytes of schizophrenic patients, showing a significant elevation of about 2 folds in their mRNA level. So, they can be used as a peripheral marker for identification and follow-up of schizophrenia.

Conclusions: Dopamine receptors D2 and D3 mRNA expression in the blood of schizophrenic patients might be used as diagnostic markers, revealing that the dopamine receptors antagonist antipsychotic are important in treatment of schizophrenia.

\section{REFERENCES}

Ahmadian S, Delavari G, Ghanbari D and Zaeifi D (2014): D3 as a Possible Marker Based on D1-D4 Dopamine Receptors Expression in Paranoid Schizophrenia Patients. J Mol Biomark Dian; 5: 171.

Ainiyet Babajohn and Rybakowski Janusz K. (2014): Suicidal Behavior in Schizophrenia may be Related to Low Lipid Levels. Med Sci Monit; 20: 1486-1490.

Amundson DM and Zhou M (1999): Fluorometric method for the enzymatic determination of cholesterol. J Biochem Biophys Methods $.38(1): 43-52$.

Asaad A. Shalanda MD, Rafek R. Abd Ellatif MD, Mohamed G. Negm MD, Amal S. El Shal and Heba Ahmed Abdelsalam (2018): Dopamine receptor D3R and D4R mRNA levels in peripheral lymphocytes in patients with schizophrenia and its correlation with severity of illness. $\mathrm{Z} \mathrm{u} \mathrm{m} \mathrm{j;} 24: 1$.

Ayano G (2016): Dopamine: Receptors, Functions, Synthesis, Pathways, Locations and Mental Disorders: Review of Literatures. JMent Disord Treat; 2: 120.

Beaulieu JM, Espinoza S, and Gainetdinov RR (2015): Dopamine receptors - IUPHAR Review 13. British Journal of Pharmacology; 172(1): 1-23.

Brisch Ralf, Saniotis Arthur, Wolf Rainer, Bielau Hendrik, Bernstein Hans-Gert, Steiner Johann, Bogerts Bernhard, Braun Katharina, Jankowski Zbigniew, Kumaratilake Jaliya, Henneberg Maciej and Gos Tomasz (2014): The role of dopamine in schizophrenia from a neurobiological and evolutionary perspective: old fashioned, but still in vogue. Front Psychiatry; 5: 47. 
Cantarelli Mda G, Tramontina AC, Leite MC and Gonçalves CA (2014): Potential neurochemical links between cholesterol and suicidal behavior. Psychiatry Res. Dec 30;220(3):745-51.

Cui Yin, Prabhu Vishwanath, Nguyen Thong Ba, Yadav Binod Kumar and Chung Young-Chul (2015): The mRNA Expression Status of Dopamine Receptor D2, Dopamine Receptor D3 and DARPP-32 in T Lymphocytes of Patients with Early Psychosis. Int $\mathbf{J}$ Mol SCI; 16: 26677-26686.

Deska -pagana K and pagana T (2005): Mosby`s Diagnostic and laboratory test reference. Seventh edition :937-938.

Dorak M (2000): Real-time PCR. Clinical chemistry; 50: 1680-2.

Ezequiel Uribe (2016): Neuropsychological subtypes of schizophrenia and prefrontal circuits. Eneurobiology; 7 (15): 280516.

Fatouros-Bergman H, Cervenka S, Flyckt L, Edman G and Farde L(2014): Meta-analysis of cognitive performance in drug-naïve patients with schizophrenia. Schizophr Res;158(1-3):156-62.

Foussias G, Agid O, Fervaha G and Remington G (2014): Negative symptoms of schizophrenia: clinical features, relevance to real world functioning and specificity versus other cns disorders. Eur Neuropsychopharmacol; 24(5): 693-709.

Friedewald WT, Levy RI and Fredrickson DS (1972): Estimation of the concentration of low-density lipoprotein cholesterol in plasma, without use of the preparative ultracentrifuge.Clin Chem. 18(6):499502.

Gauri N Savla, Lea Vella, Casey C. Armstrong, David L. Penn, and Elizabeth W. Twamley (2013): Deficits in Domains of Social Cognition in Schizophrenia: A Meta-Analysis of the Empirical Evidence. Schizophrenia Bulletin; 39(5): 979-992.

Gross G, Drescher K (2012): The role of dopamine D (3) receptors in antipsychotic activity and cognitive functions. Handb Exp Pharmacol; 213: 167-210

Grove T (1979): Effect of reagent $\mathrm{pH}$ on Determination of HDL Cholesterol by precipitation with Sodium Phosphotungstatemagnesium. Clin Chem. 25:560.

Hoen WP, Lijmer JG, Duran M, Wanders RJ, van Beveren NJ, de Haan L (2013): Red blood cell polyunsaturated fatty acids measured in red blood cells and schizophrenia: a meta-analysis. Psychiatry Res; 207: 1-12. 
Ilani Tal, Ben-Shachar Dorit, Strous Real, Mazur Marina, Sheinkman Alan, Kotler Moshe and Fuchs Sara (2001): A peripheral marker for schizophrenia: Increased levels of D3 dopamine receptor mRNA in blood lymphocytes. Proceedings of the National Academy of Sciences of the United States of America; 98: 625-8.

Kawano Mitsuhiko, Sawada Ken, Tsuru Emi, Nishihara Makoto, Kato Kunio, Honer William G. and Shimodera Shinji (2011): Dopamine receptor D3R and D4R mRNA levels in peripheral lymphocytes in patients with schizophrenia correlate with severity of illness. Open Journal of Psychiatry; 1: 33-39.

Kuepper R, Skinbjerg $M$ and Abi-Dargham A (2012): The dopamine dysfunction in schizophrenia revisited: new insights into topography and course. Handb Exp Pharmacol; 212: 1-26.

Lai Chi-Yu, Scarr Elizabeth, Udawela Madhara, Everall Ian, Chen Wei J and Dean Brian (2016): Biomarkers in schizophrenia: A focus on blood based diagnostics and theranostics. World J Psychiatr; 6(1): 102-117.

Lalovic A, Klempan T, Sequeira A, Luheshi G and Turecki G (2010): Altered expression of lipid metabolism and immune response genes in the frontal cortex of suicide completers. J Affect Disord; 120: $24-31$.

Liu L, Yuan G, Cheng Z, Zhang G, Liu X, et al. (2013): Identification of the mRNA Expression Status of the Dopamine D2 Receptor and Dopamine Transporter in Peripheral Blood Lymphocytes of Schizophrenia Patients. PLoS ONE; 8(9): e75259.

Liu Liang, Luo Yin, Zhang Guofu, Jin Chunhui, Zhou Zhenhe, Cheng Zaohuo and Yuan Guozhen (2017): Correlation of DRD2 mRNA expression levels with deficit syndrome severity in chronic schizophrenia patients receiving clozapine treatment. Oncotarget; 8(49): 86515-86526.

Madras BK (2013): History of the discovery of the antipsychotic dopamine D2 receptor: a basis for the dopamine hypothesis of schizophrenia. J Hist Neurosci; 22(1): 62-78.

Maramai S, Gemma S, Brogi S, Campiani G, Butini S, Stark H and Brindisi M (2016): Dopamine D3 Receptor Antagonists as Potential Therapeutics for the Treatment of Neurological Diseases. Frontiers in Neuroscience; 10: 451.

Mensi Rym, Messaoud Amal, Mhallah Ahmed, Azizi Islem, Salah Walid Haj, Douki Wahiba, Najjar Mohamed Fadhel and Gaia 
Lotfi (2016): The association between altered lipid profile and suicide attempt among Tunisian patients with schizophrenia. Mensi et al. Ann Gen Psychiatry; 15: 36.

Mitral S, Mahintamani T, Kavoor A R and Nizamie S H (2016): Negative symptoms in schizophrenia. Industrial Psychiatry Journal; 25(2): 135-144.

Nakajima S, Gerretsen P, Takeuchi H, Caravaggio F, Chow T, Le Foll B and Graff-Guerrero A (2013): The potential role of dopamine $\mathrm{D}_{3}$ receptor neurotransmission in cognition. European Neuropsychopharmacology: The Journal of the European College of Neuropsychopharmacology; 23(8): 799-813.

Ono Shin, Sugai Takuro, Suzuki Yutaro, Yamazaki Manabu, Shimoda Kazutaka, Mori Takao, Ozeki Yuji, Matsuda Hiroshi, Sugawara Norio, Yasui-Furukori Norio, Okamoto Kurefu, Saga Toyoaki and Someya Toshiyuki (2018): High-density lipoproteincholesterol and antipsychotic medication in overweight inpatients with schizophrenia: post-hoc analysis of a Japanese nationwide survey. Ono et al. BMC Psychiatry; 18: 180.

Peng Li, Gretchen L Snyder and Kimberly E Vancouver (2016): Dopamine Targeting Drugs for the Treatment of Schizophrenia: Past, Present and Future. Current Topics in Medicinal Chemistry; 16: 3385-3403.

Pergola G, Carlo P Di, D'Ambrosio E, Gelao B, Fazio L, Papalino M, Monda A, Scozia G, Pietrangelo B, Attrotto M, Apud JA, Chen Q, Mattay VS, Rampino A, Caforio G, Weinberger DR, Blasi G and Bertolino A (2017): DRD2 co-expression network and a related polygenic index predict imaging, behavioral and clinical phenotypes linked to schizophrenia. Translational Psychiatry; 7: e1006.

Peters BD, Machielsen MWJ, Hoen WP, Caan MWA, Malhotra AK, Szeszko PR, de Haan L (2013): Polyunsaturated Fatty Acid Concentration Predicts Myelin Integrity in Early-Phase Psychosis. Schizophrenia Bulletin; 39(4): 830-838.

Philip LR Gaskins, Maria Toledo-Rodríguez, Stephen PH Alexander and Kevin CF Fone (2016): Down-Regulation of Hippocampal Genes Regulating Dopaminergic, GABAergic, and Glutamatergic Function Following Combined Neonatal Phencyclidine and Post-Weaning Social Isolation of Rats as a Neurodevelopmental 
Model for Schizophrenia. International Journal of Neuropsychopharmacology; 19(11): 1-13.

Ramakrishna B, Murali Krishna V, Vijay Kumar $M$ and Raghuram Macharapu (2017): Triglycerides levels in schizophrenia: A comparative study among untreated, treated and their first-degree relatives. MedPulse International Journal of Medicine; 4(1): 09-14.

Rondou P, Haegeman G and Van Craenenbroeck K (2010): The dopamine D4 receptor: biochemical and signalling properties. Cell Mol Life Sci; 67:1971-1986.

Sarkar S, Hillner K and Velligan D I, (2015): Conceptualization and treatment of negative symptoms in schizophrenia. World Journal of Psychiatry; 5(4): 352-361.

Scorers B G (2010): The Effects of Cholesterol on Learning and Memory. Neuroscience and Biobehavioral Reviews; 34(8):13661379.

Solberg D K, Bentsen H, Refsum H and Andreassen O A (2015): Association between serum lipids and membrane fatty acids and clinical characteristics in patients with schizophrenia. Acta Psychiatr Sand;132: 293-300.

Solberg Dag K, Bentsen Håvard, Refsum Helge and Andreassen Ole A (2016): Lipid profiles in schizophrenia associated with clinical traits: a five year follow-up study. BMC Psychiatry; 16: 299.

Urhan-Kucuk M, Erdal M E, Ozen M E, Kula S and Hearken H (2011): Is the dopamine D3 receptor mRNA on blood lymphocytes help to for identification and subtyping of schizophrenia? Mol Biol Rep; 38: 2569-2572.

Wang X, Li J, Dong G and Yue J (2014): "The endogenous substrates of brain CYP2D". Eur J Pharmacol; 724: 211-218.

Wu Xiaoli, Huang Zeping, han hongying, Zhang Zhiyong, gang Zhaoyu, geo Xiaofeng, Dao Feici, han Zili and Zhao Jingping (2014): The comparison of glucose and lipid metabolism parameters in drug-naïve, antipsychotic-treated, and antipsychotic discontinuation patients with schizophrenia. Neuropsychiatric Disease and Treatment;10: 1361-1368.

Yadav S K, Prakash J, Chouhan S, Westfall S, Verma M, Singh T D, and Singh S P (2014): Comparison of the neuroprotective potential of Mucuna pruriens seed extract with estrogen in 1-methyl- 
4-phenyl-1,2,3,6-tetrahydropyridine (MPTP)-induced PD mice model [Abstract]. Neurochemistry International; 65: 1-13.

Young $\mathbf{J}$ and Geyer $M$ (2015): Developing treatments for cognitive deficits in schizophrenia: The challenge of translation. J Psychopharmacol; 29:178-196.

Zhang Baohua, Han Mei, Tan Shuping, Yang Fu De, Tan Yunlong, Jiang Shurong, Zhang Xiangyang and Huang Xu-Feng (2017): Gender differences measured by the MATRICS consensus cognitive battery in chronic schizophrenia patients. Scientific RepoRts;7: 11821.

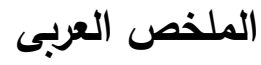

دراسة الحامض النووي الريبوزى الرسول لمستقبلات الدوبامين (ץ) و (ץ) في مرضي الفصام

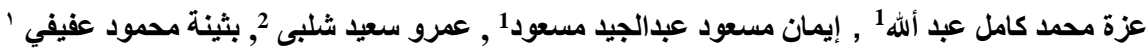

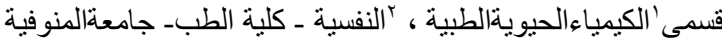

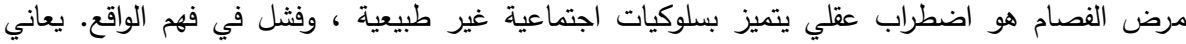
مرضي الفصام من أعراض إيجابية وتتضمن الأوهام والأفكار المضطربة والكلام، والهلاوس اللمسية والسمعية والبصرية والذوقية والتي تعتبر بالاساس أعراض الذهان.الدوبامين هو ناقل عصبي مهم في الدماغ و لهانا

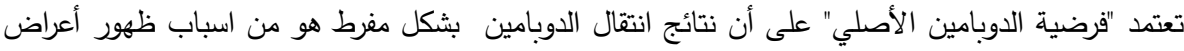

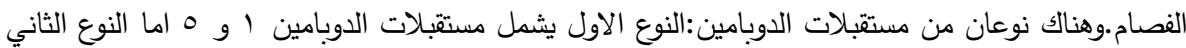

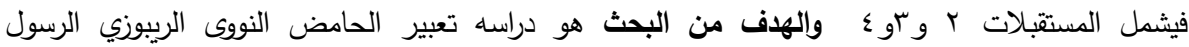

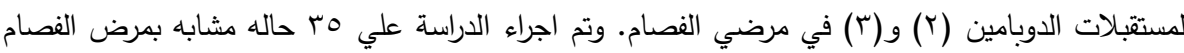
و 10 شخص كمجموعه ضابطة.

وهذه المجموعات قد خضعت لاختبارات معطلية علي عينات الدم وذلك لقياس نسبه الدهون و لتقييم التعبير

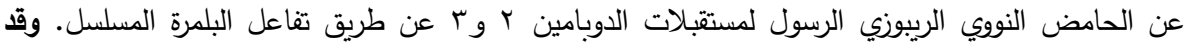
أظهرت النتائج ان هناك زيادة ذات دلالة إحصائية في مستوي البروتينات الدهنيه منخفضه ومرتنفعه الكثافه في

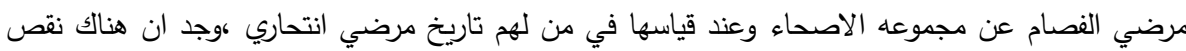

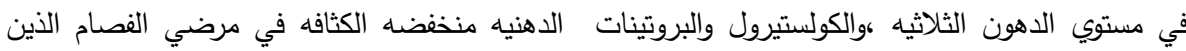

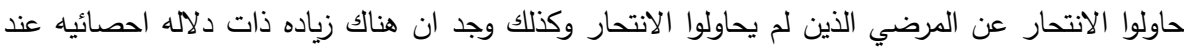

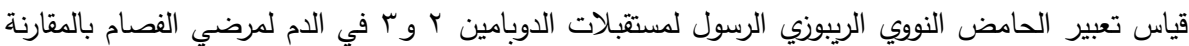

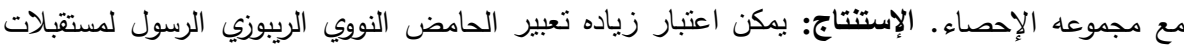

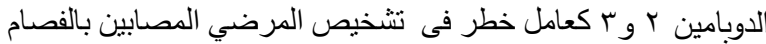

